УДК 339.138

JEL classification: M31

Пономаренко I.B.

канд. економ. наук, дочент

ORCID ID:0000-0003-3532-8332

Київський національний університет технологій та дизайну

Віннікова I.I.

канд. економ. наук, дочент ORCID ID:0000-0002-6884-0212

ДВНЗ «Київський національний економічний університет імені Вадима Гетьмана»

Гребньов Г.М.

ORCID ID:0000-0001-6836-2129

Національний технічний університет Украйни

«Київський політехнічний інститут імені Ігоря Сікорського»

\title{
ПРАКТИЧНІ АСПЕКТИ ЗАСТОСУВАННЯ ІННОВАЦЙНИХ ЦИФРОВИХ ТЕХНОЛОГІЙ В МАРКЕТИНГОВІЙ ДІЯЛЬНОСТІ
}

\section{PRACTICAL ASPECTS OF INNOVATIVE DIGITAL TECNOLOGIES APPLICATION IN MARKETING}

У статті досліджено особливості розвитку ичифрового маркетингу в сучасних умовах. Розглянуто специифіку запровадження інноваційних изифрових технологій у маркетингові діяльності. Визначено специфіку розвитку віртуальної реальності та особливості ї̈ використання у системі ичифрового маркетингу. У науковому дослідженні представлено приклади передового використання технологій віртуальної реальності компаніями світу при реалізації їх маркетингових стратегій. Висвітлено специфіку застосування технології віртуальної реальності за умови витрат значних фінансових ресурсів. Також наведено приклад використання дешевих аналогів цифррових технологій за умови використання смартфонів. Висвітлено специфіку залучення клієнтів до дешевих ичифрової технологій та особливості збільшення інтересу изільової аудиторії. Отримані результати дають можливість визначити основні тенденції розвитку ичифрового маркетингу з застосуванням технологій віртуальної реальності. У дослідженні значну увагу приділено питанням реалізації технологій використанню LED панелей. Обгрунтовано дочільність використання зазначеної технологї для indoor маркетингу - виду діяльності всередині приміщень (торговельних закладів, кафе, офісів компаній тощо) та оитыооr маркетингу - виду діяльності у зовнішньому просторі (на улииях, парках та ін.). Наведено приклади застосування LED панелей передовими компаніями світу. Висвітлено специфіку застосування даної технологї у сфері харчування. Встановлено, щзо LED панелі відіграють важливу роль у ичфровій маркетинговій стратегї кафе та ресторанів. Визначено, щуо uуифрові панелі сприяють зростанню кількості клієнтів. Доведено, щзо запровадження систем штучного інтелекту у подальшому сприятиме збільшенню інтерактивності та персоніфікаиії контенту у відповідності з умовами, які будуть проявлятись у певний момент часу в конкретному місиі. Встановлено, щчо зазначений підхід дозволить нащіональним компаніями підвищити рівень їх конкурентоспроможності на 
національному та міжнародному ринках. Доведено необхідність державної програми сприяння розвитку ичифрового маркетингу в Україні.

Ключові слова: цифровий маркетинг, віртуальна реальність, Інтернет, цифрові канали, контент.

In the article the features of development of digital marketing in modern conditions are investigated. The specifics of introduction of innovative technologies in marketing strategies of companies are considered. The specificity of the development of virtual reality and the peculiarities of its using in the digital marketing system are determined. In the scientific research, examples of the advanced use of technologies of virtual reality by companies of the world in the implementation of their marketing strategies are presented. The specificity of the application of the virtual reality technology is highlighted with the cost of significant financial resources. The example is the using of cheap analogues of digital technology such as using smartphones. The specifics of attraction the clients to cheap digital technologies and interest increase features of the target audience are highlighted. The obtained results give an opportunity to define the basic tendencies of digital marketing development with application of virtual reality technologies. The study focuses on the implementation of technology for the use of LED panels. The expediency of using this technology for indoor marketing is grounded - the type of activity in the middle of the premises (shopping centers, cafes, offices of companies, etc.) and outdoor marketing - the type of activity in the outer space (in streets, parks, etc.). One example of the using of LED panels is presented by leading companies of the world. The application specifics of this technology in the field of food are highlighted. It has been established that LED panels play the important role in the digital marketing strategy of cafes and restaurants. It is determined that digital panels help to increase the number of clients. It is proved that the introduction of artificial intelligence systems will further enhance the interactivity and personalization of content in accordance with conditions that will manifest at a certain point in time in a special place. It has been established that this approach will allow national companies to increase their competitiveness in the national and international markets. The necessity of implementation of the state program of digital marketing promotion in Ukraine has been proved.

Key words: digital marketing, virtual reality, Internet, digital channels, content.

Вступ. У сучасних умовах соціально-економічні перетворення на глобальному та національному рівнях відбуваються під впливом інтенсивного запровадження результатів сучасної науки. Важливу роль у розвитку науки та комерціалізації інноваційної продукції відіграють національні органи державного управління, які створюють відповідні умови для розвитку або деградації наукоємного сектору економіки. Усвідомлення важливості інтенсивного впровадження технологій відображається у відповідних стратегіях розвитку, орієнтованих на стале економічне зростання та посилення конкурентних позицій окремої держави у глобальному економічному середовищі. Істотну роль в інноваціях відіграють цифрові технологіï, що використовують електронне обладнання та дозволяють прискорювати i полегшувати різноманітні процеси. Цифрові технології відкривають унікальні можливості для розвитку інновацій в маркетинговій діяльності підприємств. Діджитал-технології розглядаються маркетологами як дієвий інструмент 
налагодження комунікацій з цільовою аудиторією. Інтернет речей, штучний інтелект, машинне навчання, блокчейн, технології віртуальної реальності, використанню LED панелей та інші новітні технології активно використовуються передовими компаніями світу та мають істотні перспективи для їх подальшої інтеграції у маркетингові стратегії. Окреслені технології використовуються деякими компаніями в Україні, проте існує потреба в більш активному запровадженні новітніх інструментів цифрового маркетингу в національній економічній системі.

Дослідженню питань впливу інноваційних технологій на розвиток цифрового маркетингу присвятили роботи К. Бербері, Г. Габріель, І. Додсон, Ф. Елліс-Чедвік, Б. Кіган, Д. Раян, Дж. Ровлі, Р. Хеннеберрі, А. Шарлсворт та інші відомі вчені.

Подальше дослідження пояснюється тим, що в умовах конкуренції між компаніями на глобальному та національному рівнях інтенсивний розвиток інноваційних технологій істотно впливає на їх цифрові маркетингові стратегії. Спостерігається постійна модернізація технологій, що потребує безперервного ïx моніторингу 3 метою визначення можливостей інтеграції у відповідні маркетингові інструменти. Відповідно, зростання ефективності функціонування компаній можливе лише за умових оптимізації маркетингових стратегій, важливе значення в яких відіграють інноваційні технології.

Постановка завдання. Метої статті $\epsilon$ проведення комплексного дослідження особливостей використання інноваційних технологій компаніями світу в рамках реалізації стратегій цифрового маркетингу. Аналіз основних підходів щодо застосування інноваційних цифрових технологій в маркетинговій діяльності компаній у сучасних умовах дозволить сформувати комплекс управлінських рішень для українських компаній, що сприятиме підвищенню їх конкурентоспроможності на національному та міжнародному ринках.

Методологія. При дослідженні використовувалися такі методи: діалектичний, порівняльних характеристик, наукової абстракції, економікостатистичний, графічний. Зазначені методи дали можливість проаналізувати особливості застосування інноваційних цифрових технологій в маркетинговій діяльності у сучасних умовах.

Результати дослідження. В сучасних умовах компанії на міжнародному та національному ринках використовують різноманітні підходи щодо налагодження комунікацій 3 цільовою аудиторією в рамках реалізації маркетингових стратегій. Активний розвиток інноваційних технологій призводить до трансформації інструментів цифрового маркетингу, що відображається на особливостях впливу на клієнтів. У відповідності 3 дослідженнями, значний вплив на населення спостерігається при використанні 
візуалізованого контенту. Для забезпечення оптимізації стратегій національних компаній необхідно провести комплексне дослідження підходів щодо застосування інноваційних цифрових технологій, в основі яких лежить візуалізація контенту.

Технології віртуальної реальності (VR) активно використовуються для потреб передових компаній світу при реалізації їх маркетингових стратегій. Використання технології віртуалізації дає можливість отримати новий рівень комунікацій 3 цільовою аудиторією завдяки візуальному контакту, що дозволяє користувачам відчути реальність представленої продукції та прискорити прийняття рішення про іiі придбання. Компанії використовують VR у власних рекламних стратегіях, створюючи усвідомлення у клієнтів персоніфікованого вибору [1].

The New York Times надала у безкоштовне користування найбільш лояльним передплатникам окуляри віртуальної реальності Google Cardboard як винагороду за прихильність до даного бренду. Тематично фільми VR були орієнтовані на інтелектуалів та філантропів і дозволили отримати позитивні враження завдяки перегляду пізнавального відео контенту за допомогою новітньої технології. У результаті було отримано потрійний позитивний ефект, який виражається у зростанні лояльності до бренду «New York Times», окулярів віртуальної реальності Google Cardboard та продемонстрованих фільмів.

Виробник взуття MERRELL у рамках рекламної кампанії черевиків для походів скористалась 4-D мультисенсорною технологією типу Oculus Rift. Цільовій аудиторії було запропоновано пройти туристичними маршрутами у різних типах місцевості з подоланням таких перешкод як завали каменів у горах, пошкоджені мости над прірвами тощо. Переважна більшість користувачів була у захваті від отриманих вражень завдяки реалістичності побудованої 4-D моделі.

Подібний підхід використала компанія North Face, запропонувавши користувачам здійснити віртуальну подорож до національного парку Йосеміті (США), а також у Непал. Завдяки долученню цільової аудиторії до мандрівок у користувачів формувались відчуття реальності подорожей та пов'язаної 3 цим специфіки стосовно подолання складного рельєфу, а в деяких клієнтів з'явилось бажання купувати взуття даного бренду.

Lowe's Innovation Labs створила Holoroom з використанням віртуальної реальності, що дозволяє клієнтам побачити можливі варіанти покращення інтер'єру їх домівок. Гнучкість системи дозволяє користувачам у режимі 3-D самостійно вибирати проекти, змінювати кольорові гами, комбінувати різноманітні елемента, включаючи меблі та побутову техніку тощо. Отримані результати можливо завантажити на дошки клієнтів у Pinterest. За допомогою системи віртуальної реальності компанія має можливість збирати статистичну 
інформацію про вподобання клієнтів і в подальшому використовувати отримані дані для оптимізації власної маркетингової стратегії.

Компанія IKEA також пропонує скористатись власним додатком 3 технологією VR, який дає можливість віртуально розміщувати меблі у домівках клієнтів. Практичність представленого програмного рішення дозволяє при виборі меблів враховувати їх розміри та можливості розміщення у межах площ відповідних кімнат у віртуальному середовищі.

У сучасних умовах технології віртуальної реальності активно використовуються компаніями у сфері подорожей для попередньої демонстрації клієнтам у режимі присутності готельних комплексів, окремих номерів, туристичних маршрутів, археологічних та історичних пам'яток тощо. Туристи мають унікальну можливість отримати повну інформацію про наявні продукти та вибрати найкращий варіант виходячи 3 власних можливостей та потреб. Amadeus IT Group надає можливість клієнтам у режимі віртуальної реальності замовити квитки на літак, отримавши візуальну інформацію про літак та розташування місць згідно з вибраними опціями (ціна, тип літака, дата і час поїздки тощо). Аналогічним чином можна провести віртуальний тест-драйв машин, які можна взяти в оренду під час поїздки. Навіть процес оплати послуг реалізований за допомогою технології VR, що робить більш цікавим для клієнтів стандартну за своєю суттю операцію.

Взуттєва компанія Toms за допомогою технології VR посилює емоційну стан клієнтів при покупці продукції завдяки відчуттю цільової аудиторії активними учасниками соціального проекту. При купівлі однієї пари взуття клієнтами, іншу пару Toms надсилає бідним родинам у слабо розвинені країни світу (Перу). Під час відвідування магазинів компанії клієнти можуть віртуально побачити процес перевезення та передачі безкоштовного взуття у рамках благодійного проекту. Зазначений маркетинговий інструмент позитивно впливає на посилення комунікації між цільовою аудиторією та Toms, що призводить до зростання продажів взуття.

McDonald's запропонувала клієнтам спрощений VR-пристрій, який складається на основі коробки Happy Meal та смартфону користувача. Трансформацію фірмового продукту компанії, який орієнтований на дітей, дозволила збільшити його популярність серед цільової аудиторії, а також привернути увагу старших вікових груп. Вдалий маркетинговий хід призвів до зростання продажів Нарру Meal при невеликих інвестиціях у модернізацію даного продукту. Цільова аудиторія отримала технологічний та привабливий подарунок у якості додатку до основного продукту McDonald's.

Автомобільні компанії також активно використовують технологію віртуальної реальності для налагодження комунікацій з користувачами. У даному випадку цільова аудиторія має широкі можливості для отримання комплексної інформації про продукцію автомобільних концернів без 
відвідування виставкових та торговельних представництв, а також відчуття певних емоцій від тест-драйвів, які у реальному житті вимагають певних затрат часу та фінансових ресурсів на демонстрацію можливостей автомобілів кожному клієнту окремо. Серед автомобільних концернів, які приділяють значну увагу створенню VR-контенту, слід виділити BMW GROUP, FORD GM, HONDA та інші. Цікавий контент, який має соціальну орієнтацію, випустила компанія Volvo. Компанія у рамках соціального проекту щодо мінімізації летальних випадків на дорогах запустила VR-відео, які дозволяють y режимі віртуального керування транспортними засобами здійснювати тренування у різноманітних потенційно аварійних ситуаціях 3 метою уникнення нещасних випадків [2].

У сучасних умовах при реалізації цифрових маркетингових стратегій важливе місце необхідно приділяти використанню LED панелей, що дозволяє візуалізувати різноманітний контент у відповідності зі специфікою функціонування, цілями компанії та особливостями іiі цільової аудиторії. Розміщення інтерактивної тематичної інформації на великих екранах позитивно впливає на комунікацію 3 потенційними клієнтами, оскільки професійні зняті відео-сюжети та стилізовані відповідним чином графічні матеріали викликають зацікавленість у більшості аудиторії. Представлена технологія підходить як для indoor маркетингу - виду діяльності у середині приміщень (торговельних закладів, кафе, офісів компаній тощо), так і для outdoor маркетингу - виду діяльності у зовнішньому просторі (на улицях, парках та ін.) [3, 4].

У закладах швидкого харчування активно запроваджуються цифрові меню, які представляють собою динамічні дисплеї, що містять різноманітну візуалізовану інформацію: відеоролики, меню, рисунки, фото, графіки та ін. Контент можна легко змінювати чи редагувати у відповідності 3 існуючими обставинами (день тижня, наявність спеціальних пропозицій, асортимент продукції тощо). Використання зазначеної технології дає можливість додавати RSS-канали, які міститимуть необхідну текстову інформацію.

Starbucks тестує цифрові меню у деяких закладах мережі 3 метою виявлення можливостей щодо збільшення обсягу реалізації окремих продуктових позицій, які користуються неналежним попитом, але мають потенціал до зростання продажів. Враховуючи особливості поведінки певної частини аудиторії, яка орієнтована на інтенсивний робочий темп упродовж робочого дня, компанія змінює страви до формату, що зручний для швидкого перекусу. Отримані продукти подаються у спеціалізованому контенті на LED панелях.

Поряд 3 великими цифровими екранами у закладах харчування існує можливість використовувати інші цифрові пристрої для демонстрації меню клієнтам. На ринку доцільно виділити наступні основні види: 
1. Пристрій Clover. Електронний прилад у вигляді планшету знаходиться на кожному столі у закладі харчування без можливості його перенесення. На сенсорному екрані міститься інформація про меню, яке $\epsilon$ зручним та інформативним, з яскравими зображеннями страв та необхідною інформацією про інгредієнти та ціну. Клієнти мають можливість зробити замовлення та отримати повну інформацію про вартість замовлення. Пристрій Clover дозволяє здійснити оплату за допомогою кредитної картки. У результаті компанія оптимізує витрати часу на обслуговування клієнтів, рівень лояльності користувачів зростає, збільшується обертання столів впродовж робочого дня.

2. Планшети-меню. Зазначені пристрої дають можливість переглянути клієнтам інтерактивні меню, які надають оглядову інформацію про страви та демонструють їх фотографії з високою розподільчою здатністю. Візуалізація страв сприяє зростанню апетиту у клієнтів та призводить до зростання середнього чеку. Поряд 3 цим, програмне забезпечення дає можливість отримати інформацію про чинні акції та адаптує меню у відповідності з днями тижня та періодами доби. За допомогою планшету можна викликати офіціанта та здійснити безпечну оплату за спожиті страви та інші супутні послуги. За умови наявності програм лояльності існує можливість у онлайн-режимі перевірити наявні бонусні бали та можливості для їх використання, поряд 3 цим автоматично з'явиться довідкова інформація про ймовірний обсяг чайових. Дані пристрої виступають потужним інструментом для отримання комплексної інформації про поведінку клієнтів та ставлення до брендів завдяки проведенню інтерактивних брендів. Після отримання високоякісного сервісу та оплати за нього значна кількість клієнтів погоджується пройти інтерактивні опитування.

3. Кіоск заказів з цифровим меню. еTouchMenu використовується для прискорення обслуговування у їдальнях та консесійних закладах швидкого харчування, оскільки дає можливість клієнту самостійно у простому інтуїтивному меню швидко знайти та вибрати необхідні страви. У даному випадку касир за номером замовлення приймає лише оплату, що у кінцевому рахунку призводить до зменшення обслуговуючого персоналу. За рахунок оптимізації часу на замовлення виникає можливість швидше надавати послуги клієнтам, що сприяє зростанню рівня їх задоволеності сервісом.

4. Годинник повідомлення сервісу. Для підтримки високого рівня послуг компанії у ресторанній сфері оснащують обслуговуючий персонал, в першу чергу мова йде про офіціантів, годинниками 3 повідомленнями про необхідність надання сервісу. При натисканні клієнтами сигнального пристрою на відповідному столі офіціант отримує повідомлення на годинник та має можливість оперативно взяти замовлення або розрахувати відвідувачів. Також офіціанти отримують інформації про готовність страв на кухні закладу 
харчування. Оптимізація комунікацій з клієнтами у процесі обслуговування позитивно впливає на імідж компанії та сприяє зростанню кількості клієнтів і прибутку [5].

Запровадження систем штучного інтелекту у подальшому сприятиме збільшенню інтерактивності та персоніфікації контенту у відповідності 3 умовами, які будуть проявлятись у певний момент часу в конкретному місці [6]. Система комплектується комплексом датчиків та каналами передачі даних 3 різноманітних баз даних та Інтернету, на основі спеціалізоване програмне забезпечення буде приймати рішення про тематику повідомлень. Виходячи 3 існуючих обставин алгоритм буде обирати оптимальний варіант надання інформації цільовій аудиторії або окремому клієнту з метою максимізації рівня комунікацій. Наприклад, у сонячну погоду цільовій аудиторії буде демонструватись реклама тематичних розважальних закладів або харчових продуктів і напоїв, а у дощову погоду - товарів для захисту від непогоди чи заходів у торговельно-розважальних центрах.

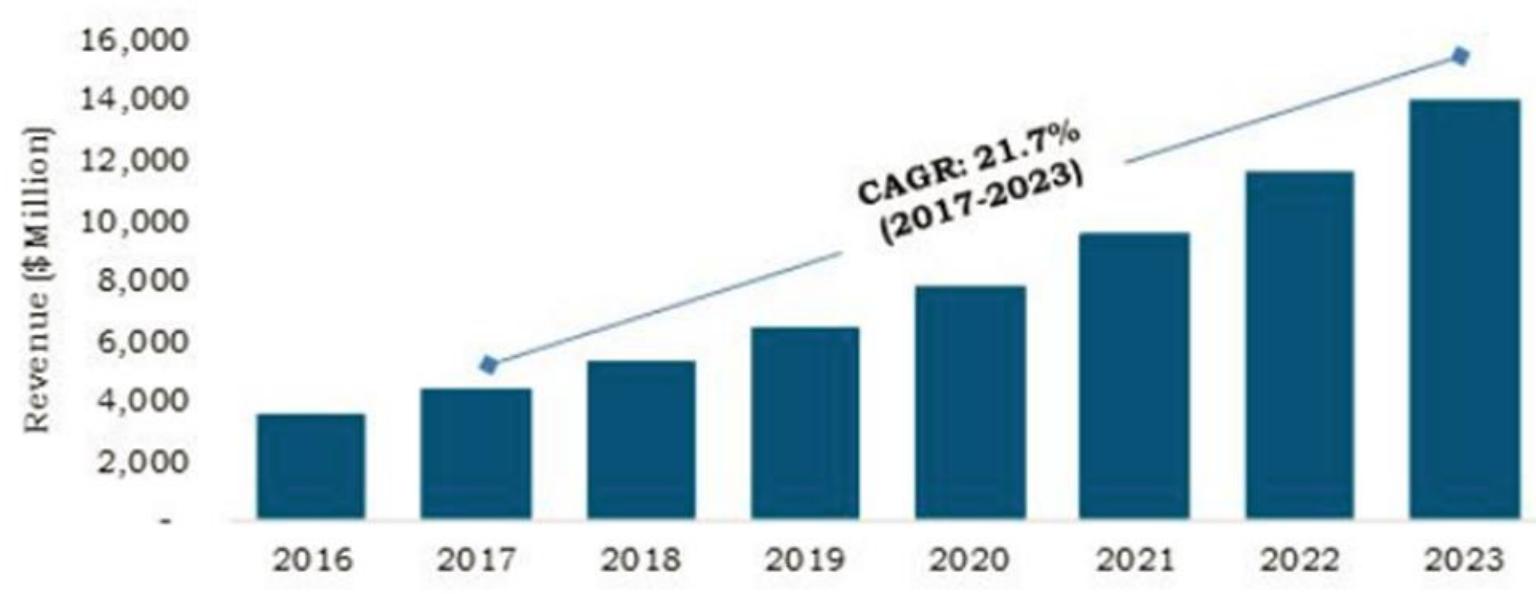

Рисунок - Динаміка ринку LED-дисплеїв за 2016-2023 pp. [7]

Як видно 3 рисунку динаміка ринку LED-дисплеїв як різновиду інноваційних цифрових технологій маркетингової діяльності підприємств в майбутньому тільки зростатиме.

Узагальнюючи викладене, слід відмітити, що кількість сучасних підприємств, які застосовують в своїй маркетинговій діяльності інноваційні цифрові технології постійно збільшується, розширюючи сфери свого використання. В глобальному економічному середовищі для посилення комунікацій з цільовою аудиторією набувать всебільшого розповсюдження два підходи цифрового маркетингу: використання технологій віртуальної реальності та візуалізація контенту за допомогою інноваційних дисплеїв різних форматів.

Висновки. У процесі наукового дослідження було встановлено, що технології віртуальної реальності (VR) активно використовуються для 
власних потреб передовими брендами світу, а українські компанії мають змогу застосовувати зарубіжний досвід, впроваджувати цифрові інноваційні технології в свою діяльність. Доведено, що інноваційні діджітал-технології можна розглядати як новий вид маркетингової діяльності, який передбачає використання цифрових інструментів налагодження стійких комунікацій 3 клієнтами та задоволення їх потреб у певних продуктах. Поряд 3 апаратним забезпеченням, сучасний цифровий маркетинг приділяє значну увагу використанню інформаційних технологій, серед яких особливо слід виділити штучний інтелект.

Наукова новизна полягає у визначенні основних підходів щодо застосування інноваційних цифрових технологій в маркетинговій діяльності компаній. Встановлено необхідність адаптації маркетингових стратегій вітчизняних підприємств до реалій глобального економічного середовища, у якому визначальну роль при побудові комунікацій 3 клієнтами відіграють цифрові технології.

Теоретичне і практичне значення результатів дослідження полягає в проведенні комплексного аналізу умов реалізації цифрових маркетингових стратегій передовими компаніями світу 3 використанням інноваційних технологій, результати якого можуть бути використані українськими підприємствами для підвищення рівня конкурентоспроможності на національному та міжнародних ринках.

Перспективи подальших наукових розробок можуть бути спрямовані на розширення та поглиблення аналітичних можливостей дослідження адаптації передового світового досвіду у сфері цифрового маркетингу до реалій української економічної системи з метою оптимізації діяльності національних компаній.

Рекомендації щодо використання національними компаніями отриманих положень у результаті наукового дослідження передбачають: приділення значної уваги вивченню передового світовому досвіду щодо запровадження інновацій у сфері цифрового маркетингу; використання ефективних діджіталінструментів для посилення комунікацій з ціловою аудиторією; застосування систем штучного інтелекту при реалізації цифрових маркетингових стратегій тощо.

\section{Література:}

1. Official site of Internet Marketing Association. URL:: https://imanetwork.org/

2. 7 Examples of Successful Virtual Reality Marketing. URL: https://digitalmarketinginstitute.com/blog/2018-01-19-7-examples-of-successful-virtual-realitymarketing

3.

Digital

Marketing

Tutorial

URL: https://www.tutorialspoint.com/digital_marketing/index.htm 
4. B. Ślusarczyk, P. Dziekański, Marketing terytorialny wyzwaniem współczesnego samorządu - wybrane zagadnienia, OSTRÓG, Ostrowiec Świętokrzyski, 2014, (B. Ślusarczyk autorstwo I, II, III i IV rozdziału, s. 1-56).

5. eTouchMenu Digital Menu - Table Ordering System by Tablet or Kiosk URL: http://etouchmenu.com/Digital-Ordering-Devices/

6. Чубукова О. Ю. Складові інноваційної економіки - освіта, технологічні уклади, когнітивні технології. Науковий вісник Полісся. - 2016. - №3 (7). - С. 130-133.

7. Outdoor Led Display Market Overview

https://www.alliedmarketresearch.com/outdoor-LED-display-market 